\title{
Bruk av andre vanedannende legemidler blant opioidbrukere med langvarige smerter
}

\author{
Ingvild Odsbu ${ }^{1}$, Marte Handal ${ }^{1}$, Vidar Hjellvik ${ }^{2}$, Petter C. Borchgrevink ${ }^{3,4}$, Thomas \\ Clausen $^{5}$, Aleksi Hamina ${ }^{5,6}$, Torgeir Gilje Lid ${ }^{7,8}$, Ragnar Nesvåg ${ }^{1}$ og Svetlana Skurtveit ${ }^{1,5}$ \\ ${ }^{I}$ Avdeling for psykiske lidelser, Område for psykisk og fysisk helse, Folkehelseinstituttet, Oslo \\ ${ }^{2}$ Avdeling for kroniske sykdommer og aldring, Område for psykisk og fysisk helse, Folkehelseinstituttet, Oslo \\ ${ }^{3}$ Avdeling for smerte og sammensatte lidelser, St. Olavs hospital, Trondheim \\ ${ }^{4}$ Institutt for sirkulasjon og bildediagnostikk, Norges teknisk-naturvitenskapelige universitet, Trondheim \\ ${ }^{5}$ Senter for rus- og avhengighetsforskning (SERAF), Institutt for klinisk medisin, Universitetet i Oslo, Oslo \\ ${ }^{6}$ School of Pharmacy, Faculty of Health Sciences, University of Eastern Finland, Kuopio, Finland \\ ${ }^{7}$ Regionalt kompetansesenter for rusmiddelforskning, Helse Stavanger HF, Stavanger \\ ${ }^{8}$ Helsevitenskapelig fakultet, Universitetet i Stavanger, Stavanger
}

Korrespondanse: Ingvild Odsbu, Avdeling for psykiske lidelser, Folkehelseinstituttet, Sandakerveien 24 C - Bygg B, 0473 Oslo E-post: ingvild.odsbu@fhi.no

\section{SAMMENDRAG}

Bakgrunn: Opioider for behandling av langvarige smerter kan forskrives på blå resept, men bør ikke brukes samtidig med andre vanedannende legemidler.

Hensikt: Å undersøke bruk av opioider på blå resept i perioden 2009-2019, samt å studere bruk av andre vanedannende legemidler (benzodiazepiner og z-hypnotika) blant dem som fikk opioider på blå resept i 2019.

Metode: Data ble hentet fra Reseptregisteret. En prevalent opioidbruker i 2019 ble definert som en person med minst én utlevering av et smertestillende opioid på blå resept for langvarige smerter også i 2018. Bruk av andre vanedannende legemidler ble definert som minst én utlevering av et annet vanedannende legemiddel i løpet av samme år.

Resultater: Totalt 18443 personer (67\% kvinner) fikk utlevert opioider på blå resept i 2019, en økning fra 5568 i 2009 via 10693 i 2016 og 16133 i 2017. Av de 18443 var 14202 (77\%) prevalente opioidbrukere. Blant de prevalente brukerne fikk $88 \%$ utlevert $100 \mathrm{mg}$ orale morfinekvivalenter (OMEQ) eller mindre per dag. Totalt fikk $54 \%$ av de prevalente opioidbrukerne utlevert minst ett annet vanedannende legemiddel i 2019. Z-hypnotika var oftest forekommende blant de som brukte $100 \mathrm{mg}$ OMEQ eller mindre per dag, mens benzodiazepiner alene eller i kombinasjon med z-hypnotika dominerte blant opioidbrukerne som fikk utlevert mer enn $100 \mathrm{mg}$ OMEQ per dag. Mengden utlevert av andre vanedannende legemidler økte med mengden opioider brukt per dag. En større andel kvinner enn menn fikk utlevert andre vanedannende legemidler i 2019.

Konklusjon: Studien indikerer at bruk av andre vanedannende legemidler forekommer hos en stor andel av dem som får forskrevet opioider på blå resept. Dette er tegn på et uheldig forskrivningsmønster som bør studeres nærmere.

Odsbu I, Handal M, Hjellvik V, Borchgrevink PC, Clausen T, Hamina A, Lid TG, Nesvåg R, Skurtveit S. Use of other addictive drugs among opioid users with chronic pain Norsk Epidemiologi 2021; 29 (1-2): 45-53.

\section{ENGLISH SUMMARY}

Background: Approximately $30 \%$ of the adult Norwegian population reports experiencing chronic pain, i.e. pain persisting more than three months. Opioids are indicated to treat moderate-to-severe pain. Since 2008, opioids can be reimbursed when prescribed for the treatment of chronic pain in Norway. Opioids have addictive potential and should, according to international and Norwegian recommendations, not be used concomitantly with other addictive drugs such as benzodiazepines (anxiolytics and sedatives) or benzodiazepine-related drugs (z-hypnotics).

Aim of study: The aim of the study was to investigate opioid use within the reimbursement scheme in the period 2009-2019 and to calculate the prevalence of use of benzodiazepines and z-hypnotics among prevalent users receiving opioids on reimbursable prescriptions in 2019.

Methods: The data were retrieved from the Norwegian Prescription Database. The study population consisted of individuals aged 18 years or older with at least one dispensation of an opioid reimbursed for chronic pain in the period 2009-2019. A prevalent user receiving opioids on reimbursable prescriptions in 2019 was defined as an individual filling at least one reimbursed opioid prescription in both 2018 and 2019. Use of other addictive drugs was defined as being dispensed at least one benzodiazepine and/or z-hypnotic in 2019 among prevalent opioid users. 
Results: Our results show an increase in the number of individuals receiving opioids on reimbursable prescripttions for the treatment of chronic pain in the period from 2009 to 2019. In 2019, there were 18,443 users of opioids on reimbursable prescriptions (67\% women). Of these, 14,202 (77\%) were prevalent opioid users. Among the prevalent opioid users, $90 \%$ of the women and $84 \%$ of the men received opioids corresponding to use of up to $100 \mathrm{mg}$ oral morphine equivalents (OMEQ) per day, while a small proportion ( $1.5 \%$ of the women, $2.9 \%$ of the men) received more than the recommended maximum dosage of $300 \mathrm{mg}$ OMEQ per day. In total, $54 \%$ of the opioid users were dispensed at least one other addictive drug in 2019. Z-hypnotics were most frequently dispensed to opioid users using $100 \mathrm{mg}$ OMEQ or less per day, whereas benzodiazepines alone or in combination with z-hypnotics were more frequently dispensed to opioid users using more than $100 \mathrm{mg}$ OMEQ per day. The total amount of dispensed benzodiazepines and/or z-hypnotics increased with an increasing number of OMEQs used per day. Women received other addictive drugs more frequently than men. In total, $24 \%$ of all the opioid users were first prescribed an opioid under the reimbursement scheme.

Interpretation of results: Our study shows that more than half of the individuals receiving opioids on reimbursable prescriptions for the treatment of chronic pain also received other addictive drugs the same year albeit recommendations discourage the use of more than one addictive drug at a time. Also, one-fourth of the individuals received opioids as the first drug under the reimbursement scheme although non-opioid analgesics should preferably be prescribed first. There is a need for observational studies using linked data from national health- and population registers to gain more knowledge about the risk factors for and consequences of use of other addictive drugs among opioid users.

This is an open access article distributed under the Creative Commons Attribution Licence, which permits unrestricted use, distribution, and reproduction in any medium, provided the original work is properly cited.

\section{INTRODUKSJON}

Ifølge den siste oppdaterte Folkehelserapporten oppgir rundt 30 prosent av den voksne norske befolkningen at de har langvarig smerte, og forekomsten er høyere blant kvinner enn menn (1). Et mindretall behandles med opioider, legemidler som virker på opioidreseptorer $\mathrm{i}$ sentralnervesystemet og som kan deles inn i svake og sterke. Svake opioider omfatter kodein og tramadol (både alene og i kombinasjon med paracetamol), mens alle andre opioider betegnes som sterke. Opioider brukes både i behandling av akutte og langvarige smerter, og i tillegg har opioidene en sentral plass $i$ lindrende behandling ved livets slutt. For behandling av pasienter med langvarige smerter er det et mål å bedre pasientenes funksjonalitet og livskvalitet, og det er per i dag manglende kunnskap om langvarig bruk av opioider kan bidra til dette.

Det har skjedd en betydelig endring i muligheten for å få refusjon for smertestillende legemidler ved behandling av langvarige smertetilstander. I 2008 førte endringer i blåreseptordningen til at pasienter med langvarige smerter, betydelig nedsatt livskvalitet og nedsatt funksjonsevne kunne få opioider og andre smertestillende legemidler gjennom blåreseptordningen (refusjonskode -71) (2,3). For å få opioider på blå resept må pasienten vanligvis først ha prøvd minst to smertestillende legemidler som ikke er opioider.

Da ordningen ble innført var det kun noen spesialister som kunne starte behandling med opioider på refusjonskode -71. I oktober 2016 ble blåreseptforskriften endret slik at også fastlegene kunne søke om individuell refusjon for opioider på blå resept til pasienter med langvarige, sterke smerter (4). Fastleger kan søke om individuell refusjon for opptil $100 \mathrm{mg}$ orale morfin- ekvivalenter (OMEQ) per dag. Det er bare leger ved tverrfaglige smerteklinikker som kan søke om individuell refusjon for daglige mengder over dette, og øvre tak er da $300 \mathrm{mg}$ OMEQ (4). I en nylig publisert studie har vi vist at det har vært en økning i totalt antall pasienter i Norge som får opioider for langvarige sterke smerter på blå resept, både blant kvinner og menn, siden ordningen ble innført i 2008, og økningen har vært størst i de eldste aldersgruppene for både kvinner og menn (3). I 2017 var det en markert økning i andelen som fikk opioider på blå resept $\mathrm{i}$ alle aldersgrupper (totalt $49 \%$ økning fra 2016), som mest sannsynlig gjenspeiler at fastlegene fikk mulighet til å forskrive opioider på blå resept. I 2018 var det 17383 voksne pasienter som fikk opioider på blå resept for langvarige, sterke smerter ( $5 \%$ økning fra 2017).

Det savnes studier om langvarig bruk av opioider blant langvarige smertepasienter på nasjonalt nivå fra andre land det er naturlig å sammenligne seg med. Når det gjelder den totale opioidbruken vet vi at den har økt i Danmark (2006-2016) og Norge (2006-2017), mens Sverige har hatt en svak nedgang fra 2013 (5). Felles for de skandinaviske landene er at det har skjedd en endring over tid i hvilke opioider som forskrives, der blant annet bruken av oksykodon, som er et sterkt opioid, øker (5). Dette er en utvikling som bør følges nøye, da økt bruk av oksykodon på resept har vært en drivende faktor bak opioidepidemien i USA (6). Et skifte til forskrivning av sterke opioider og et økende antall pasienter som får opioider forskrevet på blå resept er signaler om endringer i opioidbruken i Norge som det er viktig å følge med på $(3,5)$.

Ifølge nasjonal veileder for opioider bør pasienter som starter på et standardisert opioidregime seponere andre vanedannende legemidler som benzodiazepiner 
(angstdempende og søvnfremkallende legemidler) og benzodiazepinlignende legemidler, såkalte z-hypnotika (søvnfremkallende legemidler) (7). Disse bør ikke benyttes av pasienter som får opioider for langvarige, ikke-kreftrelaterte smerter, da disse legemidlene kan forsterke hverandres effekt og øke faren for avhengighetsutvikling, respirasjonsstans og død $(7,8)$. Det er også økt risiko for negative effekter ved samvirke med alkohol, særlig hos eldre, som har et høyere forbruk av vanedannende legemidler (9). Tidligere studier har vist at forskrivning av andre vanedannende legemidler ofte forekommer blant opioidbrukere (10-13). Det er en høyere forekomst av angst og søvnproblemer hos pasienter med langvarige, sterke smerter sammenlignet med den generelle populasjonen (14-16) og det kan være behov for å behandle disse tilstandene samtidig med smertetilstanden. Gitt den betydelige økte faren for alvorlige konsekvenser ved samtidig bruk bør det heller vurderes å trappe ned opioider dersom man skal behandle disse tilstandene med andre vanedannende legemidler, alternativt behandle komorbide lidelser med ikke-vanedannende legemidler (7).

Formålet med denne studien var å undersøke bruk av opioider forskrevet på blå resept (refusjonskode -71) for langvarige smerter. Først ville vi studere utvikling i bruk av opioider på blå resept i perioden 2009-2019. Deretter ville vi undersøke bruk av opioider på blå resept i 2019 fordelt på kjønn og alder, beregne andelen pasienter som fikk høyere doser enn anbefalt $(300 \mathrm{mg}$ OMEQ per dag) og undersøke hvilket legemiddel pasientene fikk som sitt første smertestillende legemiddel registrert på blå resept med refusjonskode -71 . Et annet formål var å studere bruk av andre vanedannende legemidler samme år blant de som fikk opioider på blå resept i 2019.

\section{MATERIALE OG METODE}

\section{Datakilde}

Reseptregisteret ble etablert i 2004 og inneholder informasjon om alle legemidler på resept som er utlevert fra alle apotek i Norge til pasienter utenfor institusjon. Legemidler forskrevet på godkjenningsfritak er også inkludert, men legemidler som selges reseptfritt er ikke registrert i Reseptregisteret. Hvis reseptfrie legemidler er forskrevet på resept, vil de imidlertid bli registrert $i$ databasen. Vanedannende legemidler utleveres på resept i Norge. Reseptregisteret inneholder informasjon om pasienten, forskrivende lege, utlevert legemiddel og indikasjon for forskrivningen (refusjonsresepter). Legemidler er klassifisert i henhold til ATC-kode (Anatomic Therapeutic Chemical classification), og indikasjon på refusjonsresepter er registrert som diagnoser $i$ henhold til International Classification of Diseases versjon 10 (ICD-10) eller International Classification of Primary Care (ICPC-2). I tillegg har Legemiddelverket på enkelte områder definert egne koder, som for eksempel refusjonskode -71 for smertestillende legemidler ved behandling av langvarige smertetilstander.

\section{Opioider}

Alle opioider i ATC-gruppen N02A (opioidanalgetika) ble inkludert i studien. Opioider i ATC-gruppene N07BC (opioider ved opioidavhengighet) og R05DA (hostedempende) ble ikke inkludert.

\section{Studieperiode}

Data for perioden 2009-2019 ble benyttet i analysene. Prevalens ble beregnet for alle år. Øvrige analyser (nye brukere, første legemiddel utlevert på refusjonskode -71 og bruk av andre vanedannende legemidler) ble bare gjort for 2019.

\section{Populasjon}

De som ble inkludert var personer 18 år og eldre som hentet ut minst ett opioid på blå resept med refusjonskode -71 i studieperioden.

\section{Brukere og andel brukere i perioden 2009-2019}

En person ble definert som bruker av et opioid på blå resept med refusjonskode -71 et gitt år dersom vedkommende var registrert i Reseptregisteret med minst én slik utlevert resept i løpet av året. Andel (\%) brukere ble definert som antall brukere per 100 innbyggere (alle over 18 år). Befolkningsgrunnlaget hvert år var middelbefolkningen (gjennomsnittet av befolkningen 1. januar og 31. desember) det aktuelle året, hentet fra Statistisk sentralbyrå.

\section{Prevalente og nye opioidbrukere i 2019}

En person ble definert som en prevalent bruker i 2019 dersom vedkommende hadde minst én utlevering av et opioid på blå resept med refusjonskode -71 også i 2018. En person ble definert som ny bruker i 2019 i henhold til tre ulike definisjoner, (i) ingen utleveringer av opioider på blå resept med refusjonskode -71 foregående kalenderår (dvs. i 2018), (ii) ingen utleveringer de 5 siste årene (dvs. i perioden 2014-2018) og (iii) ingen utleveringer siden refusjonsordningen ble innført i 2008. Andel (\%) nye brukere ble definert som antall nye brukere per totalt antall brukere som fikk opioider på blå resept i 2019 .

\section{Forste smertestillende legemiddel registrert på blå resept med refusjonskode -71}

Det første legemiddelet registrert på blå resept med refusjonskode -71 ble definert som det første legemiddelet (opioid eller ikke-opioid) en person fikk utlevert med refusjonskode -71 siden innføringen av blåreseptordningen i 2008. Dette ble studert blant alle opioidbrukerne på blåreseptordningen i 2019. Dersom en person fikk utlevert flere ulike legemidler med refusjonskode -71 på samme dag, ble alle legemidlene registrert som første utlevering med refusjonskode -71 .

\section{Orale morfinekvivalenter (OMEQ)}

I klinisk praksis forholder leger seg til opioidmengde målt i milligram OMEQ. I Reseptregisteret registreres 


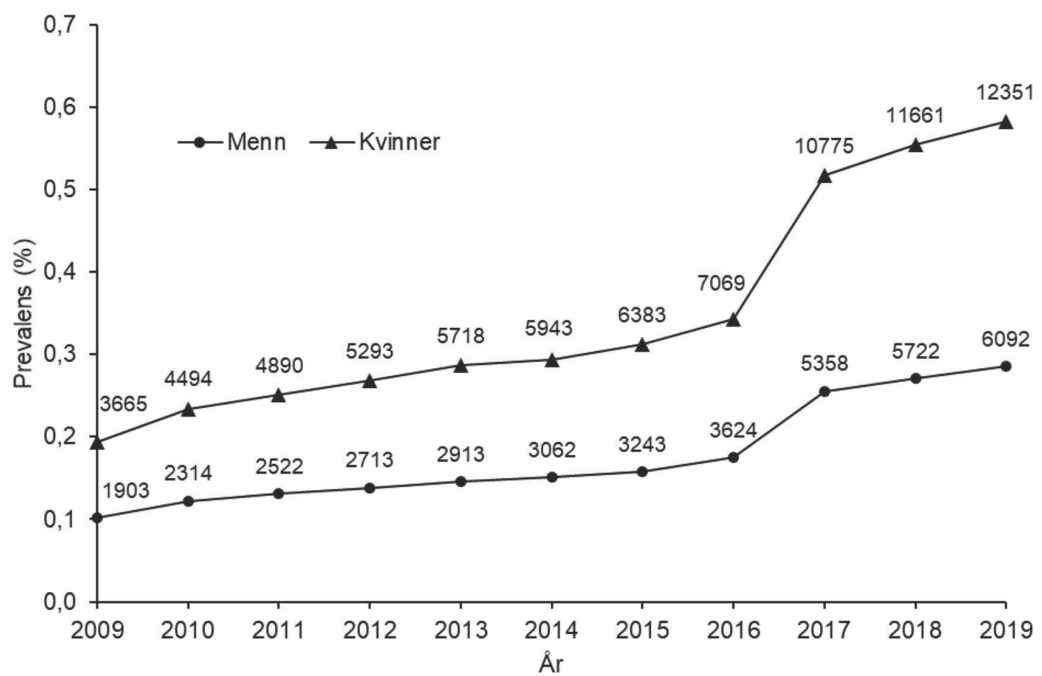

Figur 1. Andel (\%) av befolkningen som fikk minst ett opioid utlevert på blå resept med refusjonskode -71 i perioden 2009-2019 fordelt på kjønn. Antall individer er vist over datapunktene.

legemiddelmengde som er utlevert per ordinasjon i antall definerte døgndoser (DDD). DDD er den gjennomsnittlige døgndosen for en voksen person forskrevet for legemiddelets hovedindikasjon (16). For sterke opioider, som for eksempel morfin, er DDD fastsatt i forhold til hovedindikasjonen sterke smerter, mens for svake opioider, som for eksempel tramadol, er DDD fastsatt i forhold til hovedindikasjonen moderate smerter. Man kan derfor ikke anta at DDD som er fastsatt for ulike opioider representerer ekvianalgetiske doser. For bedre å kunne sammenligne ulike opioider, og også ta hensyn til administrasjonsform (ulike administrasjonsformer av samme virkestoff kan ha ulik ekvianalgetisk ratio), kan det være hensiktsmessig å omregne antall DDD som er utlevert til tilsvarende mengde i milligram OMEQ. Helfo har utarbeidet en tabell for beregning av morfin ekvianalgetisk ratio som benyttes i blåreseptordningen og derfor også i denne studien $(17,18)$. Vi beregnet morfinekvivalenter på individnivå hos alle prevalente brukere som fikk utlevert minst ett opioid (ATC N02A) på refusjonskode -71 i 2019. Antall milligram OMEQ ble beregnet ut fra antall DDD på ordinasjonsnivå for alle utleveringer av opioider i 2019 til prevalente brukere. Total mengde OMEQ utlevert i 2019 ble aggregert på individnivå. Total mengde OMEQ ble beregnet per prevalent bruker for utleveringer på blå resept og for total utlevert mengde på blå og hvit resept for prevalente brukere som hadde minst én utlevering av opioider på blå resept med refusjonskode -71. OMEQ per dag i 2019 ble beregnet ved å dividere total mengde utlevert i løpet av 2019 på 365. Vi har ikke beregnet mengde opioid utlevert for nye brukere da de kan starte behandlingen sent på året.

\section{Bruk av andre vanedannende legemidler}

Andre vanedannende legemidler inkludert i studien var benzodiazepiner (N05BA, N05CD, N03AE01) og zhypnotika (N05CF). Bruk av andre vanedannende legemidler ble definert som (i) minst én utlevering av et benzodiazepin og/eller z-hypnotikum («benzodiazepiner og/eller z-hypnotika»), (ii) minst én utlevering av et benzodiazepin og ingen utleveringer av z-hypnotika («bare benzodiazepiner»), (iii) minst én utlevering av et z-hypnotikum og ingen utleveringer av benzodiazepiner («bare z-hypnotika») og (iv) minst én utlevering av et benzodiazepin og et z-hypnotikum («både benzodiazepiner og z-hypnotika») i løpet av 2019 blant prevalente opioidbrukere. Total mengde DDD av benzodiazepiner og z-hypnotika utlevert i 2019 ble aggregert på individnivå, og median DDD og interkvartilspredning ble beregnet.

\section{RESULTATER}

\section{Utvikling $i$ bruk av opioider på refusjonskode $-71 i$ perioden 2009-2019}

Figur 1 viser utviklingen $i$ antall personer totalt og andel av befolkningen (prevalens) som fikk utlevert opioider på refusjonskode - 71 fordelt på kjønn i perioden 20092019. I 2009 fikk 5568 personer $(0,15 \%$ av befolkningen) opioider på refusjonskode -71 , mens tilsvarende antall i 2019 var 18443 (0,43\% av befolkningen). En høyere andel kvinner enn menn fikk utlevert opioider gjennom hele perioden. Økningen i andel fra et år til neste var mellom $2 \%$ og $8 \%$ for både menn og kvinner gjennom hele perioden 2010-2019, unntatt 2016-2017 da økningen var $51 \%$ for kvinner og $46 \%$ for menn, og 2015-2016 da økningen var henholdsvis 10 og 11\%.

\section{Karakteristika ved brukere av opioider på refusjons- kode -71 i 2019}

Blant de 18443 brukerne som fikk utlevert opioider på refusjonskode -71 i 2019 var det omtrent dobbelt så mange kvinner $(n=12$ 351) som menn $(n=6092)$ (Tabell 1). Gjennomsnittlig alder var 63 år for kvinner og 60 år for menn. Blant både kvinner og menn var det flest brukere i alderen 45-69 år, fulgt av personer 70 år og eldre. Blant alle som fikk utlevert opioider på refusjons- 
Tabell 1. Karakteristika ved personer over 18 år med minst én utlevering av et opioid med refusjonskode -71 i 2019.

\begin{tabular}{|c|c|c|}
\hline Karakteristika & Kvinner & Menn \\
\hline Antall brukere, $\mathrm{n}(\%)$ & $12351(67,0)$ & $6092(33,0)$ \\
\hline Alder, gjennomsnitt (standardavvik) & $63,3(16,9)$ & $59,9(14,5)$ \\
\hline \multicolumn{3}{|l|}{ Aldersgrupper, $\mathrm{n}(\%)$} \\
\hline $18-44$ & $1709(13,8)$ & $873(14,3)$ \\
\hline $45-69$ & $5918(47,9)$ & $3622(59,5)$ \\
\hline $70+$ & $4724(38,2)$ & $1597(26,2)$ \\
\hline Antall prevalente brukere*, n $(\%)$ & $9610(77,8)$ & $4592(75,4)$ \\
\hline \multicolumn{3}{|c|}{ Mengde opioid (mg OMEQ) utlevert per dag blant prevalente brukere } \\
\hline Gjennomsnitt & 46 & 61 \\
\hline Median (interkvartilspredning) & $25(10-53)$ & $30(11-69)$ \\
\hline \multicolumn{3}{|c|}{ Antall prevalente brukere fordelt på mg OMEQ utlevert per dag, $\mathrm{n}(\%)$} \\
\hline$\leq 100$ & $8601(89,5)$ & $3834(83,5)$ \\
\hline$>100-200$ & $667(6,9)$ & $481(10,5)$ \\
\hline$>200-300$ & $197(2,0)$ & $142(3,1)$ \\
\hline$>300$ & $145(1,5)$ & $135(2,9)$ \\
\hline$>300$, alle opioider**, $\mathrm{n}(\%)$ & $278(2,9)$ & $239(5,2)$ \\
\hline \multicolumn{3}{|l|}{ Nye brukere i $2019, \mathrm{n}(\%)$} \\
\hline Ingen utleveringer i perioden $2008-2018$ & $579(4,7)$ & $293(4,8)$ \\
\hline Ingen utleveringer siste 5 år (2014-2018) & $2391(19,4)$ & $1332(21,9)$ \\
\hline Ingen utleveringer foregående år (2018) & $2741(22,2)$ & $1500(24,6)$ \\
\hline
\end{tabular}

kode -71 i 2019 var det $9610(77,8 \%)$ kvinner og 4592 $(75,4 \%)$ menn som også fikk utlevert opioider i 2018 (prevalente brukere). Blant de prevalente brukerne fikk kvinner utlevert lavere doser opioider enn menn. Median dose var $25 \mathrm{mg}$ OMEQ per dag (gjennomsnitt $46 \mathrm{mg}$ OMEQ) for kvinner og $30 \mathrm{mg}$ OMEQ per dag (gjennomsnitt $61 \mathrm{mg}$ OMEQ) for menn. Majoriteten av de prevalente brukerne fikk utlevert inntil $100 \mathrm{mg}$ OMEQ per dag (89,5\% kvinner, 83,5\% menn). Andelen prevalente brukere som fikk mer enn $300 \mathrm{mg}$ OMEQ per dag var lavere for kvinner enn menn. Når mengden OMEQ utlevert på hvit resept ble inkludert ble andelen prevalente brukere som fikk mer enn 300 mg OMEQ per dag fordoblet både for kvinner og menn. Det var henholdsvis 579 (4,7\%) kvinner og 293 (4,8\%) menn som fikk utlevert opioider på blå resept for første gang i 2019 og som ikke hadde fått opioider på blå resept siden ordningen ble innført i 2008 (nye brukere). Andelen nye brukere økte med kortere utvaskingsperiode (dvs. ingen utleveringer foregående år eller de fem foregående årene) (Tabell 1).

\section{Forste smertestillende legemiddel registrert på blå resept med refusjonskode -71}

Ser vi på hvilke legemidler brukere av opioider på blå resept med refusjonskode -71 i 2019 fikk utlevert som første legemiddel på denne refusjonsordningen, viser resultatene at $76 \%$ av brukerne startet med andre smertestillende legemidler enn opioider, mens $24 \%$ startet med opioider. De tre mest brukte andre smertestillende legemidlene var paracetamol $(20,3 \%)$, gabapentin $(18,5 \%)$ og amitriptylin $(13,9 \%)$. Blant de som startet med opioi- der var lavdose buprenorfin (8,3\%), tramadol (4,7\%), kodein og paracetamol $(3,5 \%)$ og oksykodon $(3,3 \%)$ oftest forekommende som første legemiddel.

\section{Bruk av andre vanedannende legemidler i 2019}

Tabell 2 viser prevalente opioidbrukere som fikk utlevert andre vanedannende legemidler i 2019. Totalt fikk $54 \%(7639 / 14202)$ av de prevalente opioidbrukerne utlevert minst ett annet vanedannende legemiddel i tillegg til opioider på blå resept i 2019. Bruk av bare zhypnotika var vanligst forekommende ( $20 \%$ av opioidbrukerne) med en median mengde utlevert på 210 (interkvartilspredning 90-370) DDD, fulgt av bruk av bare benzodiazepiner ( $18 \%$ av opioidbrukerne) med en median mengde utlevert på 100 (25-300) DDD og bruk av både benzodiazepiner og z-hypnotika (16\% av opioidbrukerne) med en median mengde utlevert på henholdsvis 90 (25-250) DDD og 300 (120-420) DDD.

Til opioidbrukere av inntil $100 \mathrm{mg}$ OMEQ per dag ble det utlevert større mengde z-hypnotika alene (median 200 DDD) enn benzodiazepiner alene (median 90 DDD). For personer som brukte mer enn $300 \mathrm{mg}$ OMEQ per dag fikk 29\% (82/280) utlevert bare benzodiazepiner med en median mengde på 309 DDD, 12\% (34/280) bare z-hypnotika med en median mengde på 350 DDD og 26\% (73/280) både benzodiazepiner (325 DDD) og z-hypnotika (419 DDD).

Andelen opioidbrukere som bare fikk utlevert zhypnotika minket med økende mengde OMEQ utlevert per dag, mens andelen som bare fikk utlevert benzodiazepiner eller både benzodiazepiner og z-hypnotika økte med økende mengde OMEQ utlevert per dag. 
Tabell 2. Antall og andel (\%) prevalente brukere av opioider på blå resept som også fikk utlevert benzodiazepiner, z-hypnotika eller både benzodiazepiner og z-hypnotika, samt antall DDD (median) utlevert i løpet av 2019 fordelt på mengde opioid (mg OMEQ) utlevert per dag på refusjonskode -71 .

\begin{tabular}{|c|c|c|c|c|c|c|c|c|c|}
\hline \multirow[b]{2}{*}{$\begin{array}{l}\text { Antall mg } \\
\text { OMEQ } \\
\text { utlevert per } \\
\text { dag }\end{array}$} & \multirow[b]{2}{*}{$\begin{array}{l}\text { Antall individer } \\
\text { per OMEQ } \\
\text { gruppe, } \mathrm{n}\end{array}$} & \multirow{2}{*}{$\begin{array}{c}\text { Ingen } \\
\text { benzodiazepiner } \\
\text { eller z-hypnotika } \\
\\
\text { Antall, n (\%) }\end{array}$} & \multicolumn{2}{|c|}{ Bare benzodiazepiner } & \multicolumn{2}{|c|}{ Bare Z-hypnotika } & \multicolumn{3}{|c|}{ Benzodiazepiner og z-hypnotika } \\
\hline & & & $\begin{array}{c}\text { Antall, } \\
\text { n (\%) }\end{array}$ & $\begin{array}{c}\text { DDD median } \\
\text { (interkvartil- } \\
\text { spredning) }\end{array}$ & $\begin{array}{c}\text { Antall, } \\
\text { n }(\%)\end{array}$ & $\begin{array}{c}\text { DDD median } \\
\text { (interkvartil- } \\
\text { spredning) } \\
\end{array}$ & $\begin{array}{c}\text { Antall, } \\
\text { n }(\%)\end{array}$ & $\begin{array}{c}\text { DDD median } \\
\text { (interkvartil- } \\
\text { spredning), } \\
\text { benzo- } \\
\text { diazepiner }\end{array}$ & $\begin{array}{c}\text { DDD median } \\
\text { (interkvartil- } \\
\text { spredning), } \\
\text { z-hypnotika }\end{array}$ \\
\hline Totalt & 14202 & $6563(46,2)$ & $2580(18,2)$ & $100(25-300)$ & $2859(20,1)$ & $210(90-370)$ & $2200(15,5)$ & $90(25-250)$ & $300(120-420)$ \\
\hline$\leq 100$ & 12435 & $5934(47,7)$ & $2113(17,0)$ & $90(20-257)$ & $2575(20,7)$ & $200(84-364)$ & $1813(14,6)$ & $80(25-213)$ & $300(115-400)$ \\
\hline$>100-200$ & 1148 & $421(36,7)$ & $281(24,5)$ & $158(50-480)$ & $203(17,7)$ & $300(133-400)$ & $243(21,2)$ & $165(50-360)$ & $362(165-504)$ \\
\hline$>200-300$ & 339 & $117(34,5)$ & $104(30,7)$ & $298(33-600)$ & $47(13,9)$ & $270(30-400)$ & $71(20,9)$ & $200(50-450)$ & $364(100-700)$ \\
\hline$>300$ & 280 & $91(32,5)$ & $82(29,3)$ & $309(100-787)$ & $34(12,1)$ & $350(200-496)$ & $73(26,1)$ & $325(76-646)$ & $419(200-700)$ \\
\hline Kvinner & 9610 & $4054(42,2)$ & $1804(18,8)$ & 95 (25-298) & $2022(21,0)$ & $212(90-370)$ & $1730(18,0)$ & $89(25-248)$ & $300(134-420)$ \\
\hline$\leq 100$ & 8601 & $3747(43,6)$ & $1525(17,7)$ & $84(20-249)$ & $1858(21,6)$ & $210(90-364)$ & $1471(17,1)$ & $79(25-210)$ & $300(120-400)$ \\
\hline$>100-200$ & 667 & $216(32,4)$ & $170(25,5)$ & $135(47-494)$ & $119(17,8)$ & $300(165-400)$ & $162(24,3)$ & $163(49-357)$ & $385(193-513)$ \\
\hline$>200-300$ & 197 & $56(28,4)$ & $62(31,5)$ & $273(32-600)$ & $26(13,2)$ & $292(41-400)$ & $53(26,9)$ & $248(93-457)$ & $380(255-724)$ \\
\hline$>300$ & 145 & $35(24,1)$ & $47(32,4)$ & $300(75-720)$ & $19(13,1)$ & $340(199-490)$ & $44(30,3)$ & $334(89-661)$ & $505(278-775)$ \\
\hline Menn & 4592 & $2509(54,6)$ & $776(16,9)$ & $146(25-350)$ & $837(18,2)$ & $200(72-374)$ & $470(10,2)$ & $104(29-300)$ & $275(90-420)$ \\
\hline$\leq 100$ & 3834 & $2187(57,0)$ & $588(15,3)$ & $114(23-300)$ & $717(18,7)$ & $186(67-360)$ & $342(8,9)$ & $87(25-243)$ & $265(90-400)$ \\
\hline$>100-200$ & 481 & $205(42,6)$ & $111(23,1)$ & $225(60-450)$ & $84(17,4)$ & $295(101-408)$ & $81(16,8)$ & $182(55-380)$ & $300(100-447)$ \\
\hline$>200-300$ & 142 & $61(43,0)$ & $42(29,6)$ & $323(45-672)$ & $21(14,8)$ & $270(30-445)$ & $18(12,7)$ & $90(31-344)$ & $170(63-447)$ \\
\hline$>300$ & 135 & $56(41,5)$ & $35(25,9)$ & $400(113-950)$ & $15(11,1)$ & $360(240-500)$ & $29(21,5)$ & $275(67-636)$ & $330(97-545)$ \\
\hline
\end{tabular}

OMEQ $=$ orale morfinekvivalenter

$\mathrm{DDD}=$ definert døgndose

Samme mønster ble observert for kvinner og menn, og menn fikk gjennomgående større mengder benzodiazepiner utlevert enn kvinner. Bruk av andre vanedannende legemidler forekom oftere hos kvinner $(58 \%, \mathrm{n}=5556)$ enn menn $(45 \%, \mathrm{n}=2083)$, spesielt bruk av både benzodiazepiner og z-hypnotika (18\% kvinner, 10\% menn) (Tabell 2, Figur 2).

\section{DISKUSJON}

Denne studien viser en vedvarende økning i antall personer som får utlevert opioider på blå resept for behandling av langvarige smerter siden refusjonsordningen ble innført i 2008. I 2019 fikk mer enn tre ganger så mange personer utlevert opioider på blå resept sammenlignet med 2009. Mer enn halvparten av dem som fikk utlevert opioider på blå resept i 2019 fikk i tillegg utlevert benzodiazepiner og/eller zhypnotika samme år. En større andel kvinner enn menn fikk utlevert andre vanedannende legemidler i 2019.

$\mathrm{Vi}$ har tidligere vist at økning i andelen personer som fikk opioider på blå resept for langvarige smerter var spesielt markant i 2017, noe som må sees i sammenheng med at fastlegene fikk mulighet til å forskrive opioider på blå resept fra oktober 2016 (3). Den markante økningen som ble observert i 2017 flatet ut i 2018 (3), og vår studie viser en fortsatt utflating i 2019. Dette støtter oppunder tidligere tolkning om at fastlegene hadde en del pasienter til behandling med opioider for langvarige smerter som de ikke hadde henvist til spesialist, og som de fra 2016 selv fikk mulighet til å overføre til opioidbehandling på blå resept.
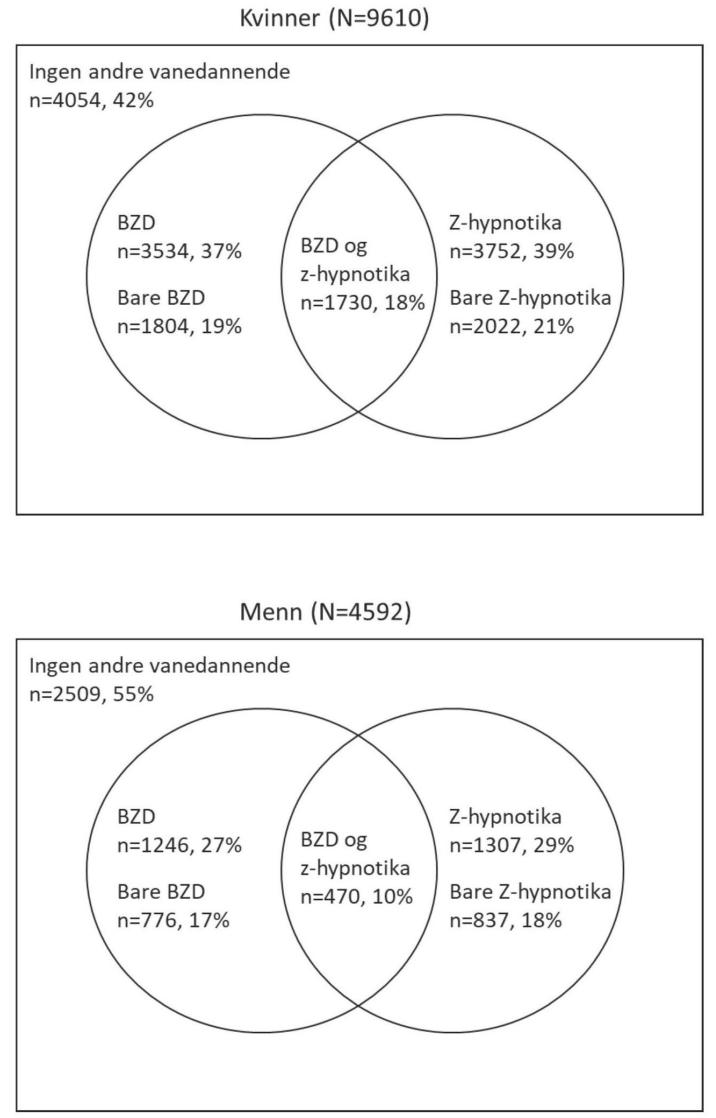

Figur 2. Venn-diagram. Totalt antall prevalente kvinner og menn (N) som fikk utlevert opioider på blå resept i 2019 er representert som firkant. Antallet (n) og andelen (\%) av disse som har ingen bruk av andre vanedannende legemidler eller som har bruk av ett eller flere vanedannende legemidler $\mathrm{i}$ 2019 er representert. BZD=benzodiazepiner. 
Flere kvinner enn menn fikk utlevert opioider på blå resept gjennom hele studieperioden. Blant prevalente opioidbrukere i 2019 fikk nærmere 90\% av kvinner og $84 \%$ av menn utlevert $100 \mathrm{mg}$ OMEQ eller mindre per dag. Median mengde opioid per dag gjennom hele året var $25 \mathrm{mg}$ OMEQ for kvinner og $30 \mathrm{mg}$ OMEQ for menn. Omregnet til kodein- og paracetamoltabletter tilsvarer dette et forbruk på rundt 17-20 tabletter daglig hele året (dvs. rundt 510-600 mg kodein daglig (maksimal døgndose for kodein er $240 \mathrm{mg}$ )). Omregnet til tramadolkapsler tilsvarer dette et forbruk på 5-6 kapsler daglig hele året (dvs. rundt 250-300 mg tramadol daglig (maksimal døgndose er $400 \mathrm{mg}$ )). Dette indikerer at disse personene sannsynligvis bruker opioider hver dag gjennom hele året. I tillegg var det en liten andel prevalente brukere som fikk utlevert over anbefalt nivå på $300 \mathrm{mg}$ OMEQ per dag, og denne andelen ble fordoblet når utleveringer på hvit resept ble inkludert i tillegg til blå resept. Muligheten til å forskrive opioider på både blå og hvit resept bør derfor undersøkes nærmere.

Rundt $22 \%$ av kvinnene og $25 \%$ av mennene som fikk utlevert opioider på blå resept i 2019 hadde ikke fått utlevert opioider på blå resept foregående år (og rundt $20 \%$ om man ser tilbake 5 år). Setter man et strengere krav til definisjonen av en ny bruker, dvs. at vedkommende ikke skal ha hatt noen utleveringer på blå resept siden innføringen av refusjonsordningen (perioden 2008-2018), var det rundt 5\% av kvinner og menn som fikk utlevert opioider på blå resept for første gang i 2019. Dette tyder på at det er noen opioidbrukere som har gått av og på ordningen i løpet av perioden.

Blant dem som fikk utlevert opioider på blå resept $\mathrm{i}$ 2019 (både prevalente og nye brukere), fikk 24\% utlevert et opioid som første legemiddel på refusjonskode -71 selv om retningslinjene sier at andre smertestillende legemidler enn opioider vanligvis skal prøves før man forskriver opioider $(2,4)$. En grunn til dette kan være at enkelte personer kan ha fătt forskrevet andre smertestillende legemidler, som f.eks. paracetamol og NSAIDs på hvit resept (eller kjøpt disse reseptfritt) og at det derfor allerede er avklart at disse legemidlene ikke har tilstrekkelig effekt. En annen forklaring kan være at enkelte personer allerede har vært i gang med behandling med opioider på hvit resept med god effekt. Forskrivning av smertestillende legemidler på hvit resept før første utlevering av opioider på blå resept ble ikke undersøkt i denne studien.

Både nasjonal veileder for vanedannende legemidler og nasjonal veileder for opioider slår fast at bruk av andre vanedannende legemidler ikke bør forekomme hos pasienter som får opioider for behandling av langvarige smerter $(7,8)$. I løpet av 2019 fikk hele $54 \%$ av de prevalente opioidbrukerne utlevert minst ett annet vanedannende legemiddel i tillegg til opioider på blå resept. Det er vel kjent at pasienter med langvarige smerter ofte kan ha angst og søvnproblemer i tillegg, men benzodiazepiner og z-hypnotika er avhengighetsskapende og skal bare brukes i korte perioder (2-4 uker).
Mengdene av andre vanedannende legemidler som en stor andel av opioidbrukerne fikk utlevert, indikerer imidlertid langvarig bruk. Blant opioidbrukerne som bare brukte benzodiazepiner (18\%) eller bare zhypnotika $(20 \%)$ i tillegg, ble det utlevert en median mengde på henholdsvis 100 DDD og 210 DDD, noe som tilsvarer over tre og seks måneders sammenhengende bruk. Blant opioidbrukerne som fikk utlevert både benzodiazepiner og z-hypnotika (16\%), var tilsvarende mengder utlevert henholdsvis 90 DDD og 300 DDD. En norsk studie fra 2008 viste at rundt $60 \%$ av langtidsbrukere av opioider fikk utlevert minst ett benzodiazepin eller z-hypnotikum i tillegg til opioider, og mengdene utlevert indikerte regelmessig bruk av disse (11). Rundt $15-18 \%$ av opioidbrukerne fikk utlevert både benzodiazepiner og z-hypnotika med mengder som indikerte regelmessig bruk av begge legemiddelgrupper (11). Da opioidbrukere og bruk av andre vanedannende legemidler er definert ulikt $i$ nevnte artikkel og denne studien er resultatene ikke direkte sammenlignbare så vi kan ikke si noe om utviklingen $\mathrm{i}$ bruk av andre vanedannende legemidler, men vi kan slå fast at det var en utstrakt bruk av andre vanedannende legemidler blant pasienter som fikk utlevert opioider for behandling av langvarige ikke-kreftrelaterte smerter også i 2019. I en studie fra Danmark ble det rapportert om en nedgang i samtidig bruk av benzodiazepiner og z-hypnotika blant langtidsbrukere av opioider fra $60 \% \mathrm{i}$ 2000 til 33\% i 2013, og et skifte i forskrivningsmønsteret fra benzodiazepiner til z-hypnotika (17). Om tilsvarende har skjedd i Norge krever mer detaljerte analyser som er utenfor rammen til denne studien.

Forekomst av bruk av de ulike andre vanedannende legemidlene endret seg med mengden opioider brukt per dag. Bruk av z-hypnotika alene forekom oftest hos opioidbrukerne som fikk utlevert inntil $100 \mathrm{mg}$ OMEQ per dag. Med økende mengder opioider utlevert per dag minket andelen opioidbrukere som bare fikk utlevert zhypnotika i tillegg, mens andelen opioidbrukere som fikk utlevert benzodiazepiner, enten alene eller i kombinasjon med z-hypnotika, økte med økende mengde opioider utlevert per dag. Blant opioidbrukerne som fikk utlevert over $300 \mathrm{mg}$ OMEQ per dag, dvs. over maksimalt anbefalt dosering, fikk $29 \%$ utlevert benzodiazepiner i tillegg med en median mengde på 309 DDD, $12 \%$ fikk utlevert z-hypnotika i tillegg (median 350 DDD) og 26\% fikk utlevert både benzodiazepiner (median 325 DDD) og z-hypnotika (median 419 DDD) i tillegg, noe som indikerer kontinuerlig bruk gjennom året. Dette viser en utstrakt bruk av andre vanedannende legemidler i tillegg til opioider, spesielt for de som fikk utlevert store mengder opioider per dag, men også hos de som fikk utlevert mindre mengder.

Vi fant en høyere forekomst av bruk av andre vanedannende legemidler hos kvinner enn hos menn, både for benzodiazepiner og z-hypnotika alene og benzodiazepiner og z-hypnotika i kombinasjon. Kombinasjonsbruk av flere vanedannende legemidler er også hyppigst forekommende blant kvinner når man ser på 
alle opioidbrukere (palliativ behandling ekskludert), dvs. ikke bare hos de som får opioider på blå resept for langvarige smerter (12).

Salg av benzodiazepiner i den generelle befolkningen har gått ned, noe som sammenfaller med økende fokus på bruk av benzodiazepiner og problemer knyttet til negative effekter som bivirkninger, misbruk og avhengighet (12). Som søvnmiddel dominerer z-hypnotika som har kortere halveringstid enn benzodiazepiner og som dermed gir mindre ettervirkninger dagen etter inntak. For brukerne av inntil $100 \mathrm{mg}$ OMEQ per dag ble benzodiazepiner utlevert i mindre grad enn zhypnotika, noe som kan være en følge av økt fokus på negative effekter av benzodiazepiner. For brukerne av mer enn 100 mg OMEQ per dag, derimot, var det en større andel som fikk utlevert benzodiazepiner alene eller benzodiazepiner og z-hypnotika i kombinasjon enn andelen som fikk utlevert bare z-hypnotika. Komedisinering med benzodiazepiner er assosiert med utvikling av avhengighet hos brukere av opioider mot langvarige smerter (18). En nylig publisert studie fra Canada viste en assosiasjon mellom samtidig bruk av benzodiazepiner og økt risiko for sykehusinnleggelser og økt totaldødelighet blant brukere av reseptbelagte opioider (19). Det er da uheldig at brukerne av store mengder opioider står mer eller mindre kontinuerlig på benzodiazepiner. Samtidig bruk av benzodiazepiner og z-hypnotika skal ikke forekomme da disse legemiddelgruppene har samme virkningsmekanisme (20). Vår studie viser økt forekomst av bruk av benzodiazepiner og z-hypnotika med økende mengde opioider utlevert per dag.

\section{Begrensninger}

Reseptregisteret inneholder opplysninger om reseptbelagte legemidler utlevert fra apotek. Vi vet derfor ikke om pasientene faktisk har brukt legemidlene og kan dermed ha overestimert antallet brukere av de ulike legemidlene. Legemidler administrert på sykehus eller sykehjem registreres ikke i Reseptregisteret på individnivå og kan derfor ha fort til en underestimering av antall legemiddelbrukere, særlig hos de eldste brukerne. Beregning av gjennomsnittlig antall OMEQ per dag ble beregnet for 365 dager og ikke det eksakte antallet dager som en person hadde opioider tilgjengelig og vi kan dermed ha underestimert gjennomsnittlig antall OMEQ per dag. Spesielt for nye brukere vil dette kunne være et problem da de kan ha sin første utlevering sent på året. På bakgrunn av dette har vi valgt å bare studere mengde OMEQ utlevert per dag for prevalente brukere som mest sannsynlig henter ut opioider gjennom hele året. Bruk av andre vanedannende legemidler ble defi- nert som minst én utlevering av et annet vanedannende legemiddel i løpet av et år. Vi vet ikke om legemidlene faktisk ble brukt samtidig. Da vi har studert bruk av andre vanedannende legemidler blant prevalente opioidbrukere med en median mengde opioid utlevert per dag som tilsvarer et høyt og kontinuerlig forbruk av opioider, mener vi at det er stor sannsynlighet for samtidig bruk i perioder, spesielt med tanke på at mengden utlevert av andre vanedannende legemidler tilsvarer flere måneders forbruk. Vi har brukt DDD som et mål på antall dager med tilgjengelig legemiddel for z-hypnotika og benzodiazepiner. Det er viktig å påpeke at DDD er den gjennomsnittlige døgndosen for legemiddelets hovedindikasjon og at det kan finnes tablettstyrker og doseringsintervaller som ikke stemmer overens med DDD. Da informasjon om dosering av legemiddelet ikke finnes tilgjengelig i Reseptregisteret vil DDD være et godt alternativt mål på behandlingsintensitet.

\section{KONKLUSJON}

I perioden 2009-2019 har det vært en vedvarende økning i antall personer som får opioider på blå resept for behandling av langvarige smerter. Selv om de fleste personene i blåreseptordningen fikk utlevert $100 \mathrm{mg}$ OMEQ eller mindre per dag, tilsvarer utlevert mengde at personene hadde store mengder opioider tilgjengelig hver dag gjennom hele året. Samtidig bruk av flere vanedannende legemidler kan, avhengig av dose, gi uheldige bivirkninger og i ytterste konsekvens være livstruende. Denne studien viser flere forskrivningsmønstre som ikke er i tråd med gjeldende nasjonale veiledere. Mer enn halvparten av de som fikk utlevert opioider på blå resept for behandling av langvarige smerter i 2019, fikk også utlevert et annet vanedannende legemiddel, og mengden utlevert av andre vanedannende legemidler økte med mengden opioider brukt per dag. En fjerdedel av pasientene fikk opioider utlevert som første legemiddel i refusjonsordningen og blant storbrukerne av opioider fikk noen utlevert opioider på både blå og hvit resept i 2019. Samlet gir resultatene fra denne studien en indikasjon på et uheldig forskrivningsmønster blant en stor del av opioidbrukerne, og funnene har dermed klinisk relevans. Videre studier der man kobler Reseptregisterdata til andre datakilder kreves for å forstå mer om risikofaktorer for og konsekvenser av samtidig bruk av opioider og andre vanedannende legemidler.

\section{Finansiering}

Svetlana Skurtveit og Ingvild Odsbu er delfinansiert av NFR prosjektnummer 320360 .

\section{REFERANSER}

1. Folkehelseinstituttet. Helsetilstanden i Norge 2018 [Public health in Norway 2018]. Rapport 2018; Oslo, 2018. Tilgjengelig fra: https://www.fhi.no/nettpub/hin/ [Lest 29.09.2020].

2. Helfo. Individuell stønad til opioider. Tilgjengelig fra: https://www.helfo.no/regelverk-ogtakster/blareseptordningen-forhandsgodkjent-og-individuell-stonad/blaresept-og-individuellstonad/individuell-stonad-til-opioider/individuell-stonad-til-opioider [Lest 06.10.2020]. 
3. Skurtveit S, Hjellvik V, Sakshaug S, Borchgrevink PC, Larsen BM, Clausen T, et al. Forskrivning av opioider på blå resept mot langvarige smerter. Tidsskr Nor Legeforen 2020. doi: 10.4045/tidsskr.20.0153.

4. Statens legemiddelverk. Nytt om legemidler. Individuell stønad til opioider ved kroniske ikke-maligne smerter. Tilgjengelig fra:

https://legemiddelverket.no/Documents/Bivirkninger\%20og\%20sikkerhet/R\%C3\%A5d\%20til\%20helseperso nell/NYL/2017/2017_NYL\%20nr.6_lavoppl\%C3\%B8slig.pdf [Lest 06.10.2020].

5. Muller AE, Clausen T, Sjøgren P, Odsbu I, Skurtveit S. Prescribed opioid analgesic use developments in three Nordic countries, 2006-2017. Scand J Pain 2019;19(2):345-53.

6. Skolnick P. The opioid epidemic: Crisis and solutions. Annu Rev Pharmacol Toxicol 2018;58:143-59.

7. Helsedirektoratet. Opioider. Nasjonal veileder. Tilgjengelig fra: https://www.helsedirektoratet.no/veiledere/opioider [Lest 06.10.2020].

8. Helsedirektoratet. Vanedannende legemidler. Nasjonal veileder. Tilgjengelig fra: https://www.helsedirektoratet.no/veiledere/vanedannende-legemidler [Lest 06.10.2020].

9. Tevik K, Selbæk G, Engedal K, Seim A, Krokstad S, Helvik AS. Use of alcohol and drugs with addiction potential among older women and men in a population-based study. The Nord-Trøndelag Health Study 20062008 (HUNT3). PLoS One 2017;12(9):e0184428.

10. Koffel E, DeRonne B, Hawkins EJ. Co-prescribing of opioids with benzodiazepines and other hypnotics for chronic pain and insomnia: Trends and health outcomes. Pain Med 2020;21(10):2055-9.

11. Mellbye A, Svendsen K, Borchgrevink PC, Skurtveit S, Fredheim OM. Concomitant medication among persistent opioid users with chronic non-malignant pain. Acta Anaesthesiol Scand 2012;56(10):1267-76.

12. Skurtveit S, Sakshaug S, Hjellvik V, Berg C, Handal M. Bruk av vanedannende legemidler i Norge 2005 - 2013. Rapport 2014. Folkehelseinstituttet, Oslo, 2014. Tilgjengelig fra: https://www.fhi.no/globalassets/ dokumenterfiler/rapporter/2014/bruk-av-vanedannende-legemidler-pdf.pdf [Lest 16.10.2020].

13. Sun EC, Dixit A, Humphreys K, Darnall BD, Baker LC, Mackey S. Association between concurrent use of prescription opioids and benzodiazepines and overdose: retrospective analysis. BMJ 2017;356:j760.

14. Mellbye A, Karlstad Ø, Skurtveit S, Borchgrevink PC, Fredheim OM. Co-morbidity in persistent opioid users with chronic non-malignant pain in Norway. Eur J Pain 2014;18(8):1083-93.

15. Nijs J, Mairesse O, Neu D, Leysen L, Danneels L, Cagnie B, et al. Sleep disturbances in chronic pain: Neurobiology, assessment, and treatment in physical therapist practice. Phys Ther 2018;98(5):325-35.

16. van Hecke O, Torrance N, Smith BH. Chronic pain epidemiology and its clinical relevance. Br J Anaesth 2013;111(1):13-8.

17. Birke H, Kurita GP, Sjøgren P, Højsted J, Simonsen MK, Juel K, et al. Chronic non-cancer pain and the epidemic prescription of opioids in the Danish population: trends from 2000 to 2013. Acta Anaesthesiol Scand 2016;60(5):623-33.

18. Højsted J, Nielsen PR, Guldstrand SK, Frich L, Sjøgren P. Classification and identification of opioid addiction in chronic pain patients. Eur J Pain 2010;14(10):1014-20.

19. Sharma V, Simpson SH, Samanani S, Jess E, Eurich DT. Concurrent use of opioids and benzodiazepines/Zdrugs in Alberta, Canada and the risk of hospitalisation and death: a case cross-over study. BMJ Open 2020; 10:e 038692 .

20. Handal M, Skurtveit S, Mørland JG. [Co-medication with benzodiazepines]. Tidsskr Nor Laegeforen 2012; 132(5):526-30. 